medRxiv preprint doi: https://doi.org/10.1101/2021.07.04.21259980; this version posted July 6,2021 . The copyright holder for this preprint (which was not certified by peer review) is the author/funder, who has granted medRxiv a license to display the preprint in perpetuity. All rights reserved. No reuse allowed without permission.

\title{
The impact of demographic factors on the accumulated number of COVID-19 cases per capita in Europe and the regions of Ukraine in the summer of 2021
}

\author{
Igor Nesteruk \\ Institute of Hydromechanics, National Academy of Sciences of Ukraine, Kyiv, Ukraine \\ Igor Sikorsky Kyiv Polytechnic Institute, Kyiv, Ukraine. \\ inesteruk@yahoo.com
}

Oleksii Rodionov

Private consulting office, Kyiv, Ukraine

\begin{abstract}
The accumulated number of COVID-19 cases per capita is an important characteristic of the pandemic dynamics that may also indicate the effectiveness of quarantine, testing and vaccination. As this value increases monotonically over time, the end of June 2021 was chosen, when the growth rate in Ukraine and the vast majority of European countries was small. This allowed us to draw some intermediate conclusions about the influence of the volume of population, its density, and the level of urbanization on the accumulated number of laboratory-confirmed cases per capita in European countries and regions of Ukraine. A simple analysis showed that the number of cases per capita does not depend on these demographic factors, although it may differ by about 4 times for different regions of Ukraine and more than 9 times for different European countries. The number of COVID-19 per capita registered in Ukraine is comparable with the same characteristic in other European countries but much higher than in China, South Korea and Japan.
\end{abstract}

Keywords: COVID-19 pandemic, epidemic dynamics in Europe, epidemic dynamics in Ukraine, mathematical modeling of infection diseases, statistical methods.

\section{Introduction}

The accumulated number of COVID-19 cases per capita (CC) may indicate the effectiveness of quarantine, testing, vaccination, and also characterizes the virulence of coronavirus strains circulating in a particular region. The $\mathrm{CC}$ values increase monotonically over time, so it is important to fix the appropriate time and compare these values for different countries and regions. In particular, in this study we take the end of June 2021, when the CC growth rate in Ukraine and the vast majority of European NOTE: This preprint reports new research that has not been certified by peer review and should not be used to guide clinical practice. countries was small. The CC numbers are regularly reported by World Health 
Organization, [1] and COVID-19 Data Repository by the Center for Systems Science and Engineering (CSSE) at Johns Hopkins University (JHU), [2].

The impact of some eco-demographic factors on the COVID-19 pandemic dynamics was studied in [3-19]. The influence of the population volume $N_{p o p}$ on the final sizes $V_{\infty}$ of the first pandemic waves in different countries and regions was studied in [19] and compared with the real CC values at fixed moments of time. In particular, relative final size of the first epidemic wave $\bar{V}_{\infty}$ was approximated by following equations:

$$
\begin{gathered}
\bar{V}_{\infty} \equiv \frac{V_{\infty}}{N_{p o p}}=0.0018546 N_{p o p}^{-0.11} \\
\bar{V}_{\infty} \equiv \frac{V_{\infty}}{N_{p o p}}=0.0013101 N_{p o p}^{0.0778}
\end{gathered}
$$

with the use results of SIR simulations for $n=13$ countries and regions and the results for $\mathrm{n}=11$ (without mainland China and South Korea), respectively.

In this paper we will study the influence of the volume of population $N_{p o p}$, its density, and the level of urbanization $N_{u b r} / N_{p o p}\left(N_{u b r}\right.$ is the number of people living in cities) on the accumulated number of laboratory-confirmed cases per capita in European countries and regions of Ukraine.

\section{Data}

We will use the data set regarding the numbers of laboratory-confirmed COVID-19 cases in the regions of Ukraine accumulated at the time June 27, 2021 and registered by national statistics, [20]. The corresponding CC numbers (per 100 persons of population) and demographic data sets for Ukrainian regions [21] are shown in Table 1. As the information from the regions of Ukraine fully or partially occupied by the Russian Federation is inaccurate, we excluded from consideration Donetsk and Luhansk regions, Crimea and Sevastopol. It can be seen that $\mathrm{CC}$ values vary from 2.25 (Kirovohrad oblast) to 8.84 (Chernivtsi oblast). Rather high CC values were registered in Zhytomyr, Khmelnytskyi, Kyiv (oblast and city), and Sumy regions that are not in the west of Ukraine with traditionally close ties with the EU countries.

The $\mathrm{CC}$ figures (per 1,000,000 persons of population) accumulated at the time June 28, 2021 and registered by JHU, [2] are shown in Table 2, which contains also the demographic data sets for European countries taken from [22-24]. The highest CC levels were registered in Andorra - 18\%, Montenegro - 16\%, Czech Republic - 15.5\%, San 
medRxiv preprint doi: https://doi.org/10.1101/2021.07.04.21259980; this version posted July 6,2021 . The copyright holder for this preprint (which was not certified by peer review) is the author/funder, who has granted medRxiv a license to display the preprint in perpetuity. All rights reserved. No reuse allowed without permission.

Marino - $15 \%$, Slovenia $-12.4 \%$. The populations of these countries are not very high as well as populations of Iceland and Finland where the lowest $\mathrm{CC}$ values were registered (1.9\% and $1.7 \%$, respectively). More than a tenfold difference in values raises a reasonable question about its causes. They may be related to the population density or the level of urbanization. A possible relationship with these factors will be explored further.

\begin{tabular}{|c|c|c|c|c|}
\hline Oblast (region) & $\begin{array}{c}\text { Population, } \\
N_{p o p}, \\
\text { [21] }\end{array}$ & $\begin{array}{c}\begin{array}{c}\text { Urban } \\
\text { population, }\end{array} \\
N_{u b r}, \\
\text { [21] }\end{array}$ & $\begin{array}{c}\text { Population } \\
\text { density (number } \\
\text { of people per } \\
\text { square } \\
\text { kilometer), [21] }\end{array}$ & $\begin{array}{c}\text { Accumulated } \\
\text { number of } \\
\text { laboratory- } \\
\text { confirmed cases } \\
\text { per hundred, } \\
\text { [20] }\end{array}$ \\
\hline Vinnytsia & 1545416 & 799385 & 58.29 & 4.67 \\
\hline Volyn & 1031421 & 539179 & 51.2 & 6.06 \\
\hline Dnipropetrovsk & 3176648 & 2668744 & 99.54 & 4.33 \\
\hline Zhytomyr & 1208212 & 716457 & 40.5 & 7.43 \\
\hline Zakarpattia & 1253791 & 465904 & 98.13 & 4.98 \\
\hline Zaporizhzhia & 1687401 & 1306231 & 62.08 & 6.30 \\
\hline Ivano-Frankivsk & 1368097 & 606764 & 98.23 & 6.38 \\
\hline Kyiv (oblast) & 1781044 & 1105383 & 63.31 & 7.12 \\
\hline Kirovohrad & 933109 & 591944 & 37.95 & 2.25 \\
\hline Lviv & 2512084 & 1534040 & 115.06 & 5.52 \\
\hline Mykolaiv & 1119862 & 768022 & 45.53 & 6.34 \\
\hline Odesa & 2377230 & 1597062 & 71.37 & 5.95 \\
\hline Poltava & 1386978 & 867201 & 48.25 & 5.70 \\
\hline Rivne & 1152961 & 548088 & 57.51 & 6.93 \\
\hline Sumy & 1068247 & 741430 & 44.82 & 7.43 \\
\hline Ternopil & 1038695 & 473727 & 75.14 & 6.82 \\
\hline Kharkiv & 2658461 & 2158121 & 84.62 & 5.66 \\
\hline Kherson & 1027913 & 631317 & 36.12 & 3.53 \\
\hline Khmelnytskyi & 1254702 & 720752 & 60.82 & 7.18 \\
\hline Cherkasy & 1192137 & 678682 & 57.04 & 6.97 \\
\hline Chernivtsi & 901632 & 390551 & 111.35 & 8.94 \\
\hline Chernihiv & 991294 & 649063 & 31.11 & 5.92 \\
\hline Kyiv (city) & 2967360 & 2967360 & 3536.78 & 7.22 \\
\hline
\end{tabular}

Table 1. Demographic characteristics and the accumulated number of laboratoryconfirmed COVID-19 cases in the regions of Ukraine as of June 27, 2021 
medRxiv preprint doi: https://doi.org/10.1101/2021.07.04.21259980; this version posted July 6,2021 . The copyright holder for this preprint (which was not certified by peer review) is the author/funder, who has granted medRxiv a license to display the preprint in perpetuity. All rights reserved. No reuse allowed without permission.

\begin{tabular}{|c|c|c|c|c|}
\hline Country & $\begin{array}{l}\text { Population, } \\
\text { [22] }\end{array}$ & $\begin{array}{c}\text { Urbanization } \\
N_{u b r} / N_{p o p}, \%, \\
\text { [23] }\end{array}$ & $\begin{array}{c}\text { Population } \\
\text { density (per } \\
\text { quare km), [24] }\end{array}$ & $\begin{array}{l}\text { Total cases per } \\
\text { million, [2] }\end{array}$ \\
\hline Monaco & 38682 & 100 & 15,47 & 65615.126 \\
\hline Holy See (Vatican City) & 801 & 100 & 2,273 & 33374.536 \\
\hline Malta & 514564 & 95 & 1,447 & 69330.229 \\
\hline San Marino & 33785 & 97 & 561 & 150008.84 \\
\hline Netherlands & 17059560 & 91 & 416 & 99886.646 \\
\hline Belgium & 11482178 & 98 & 384 & 93486.963 \\
\hline United Kingdom & 67141684 & 83 & 270 & 70284.988 \\
\hline Liechtenstein & 37910 & 14 & 245 & 79555.288 \\
\hline Luxembourg & 604245 & 91 & 243 & 112850.972 \\
\hline Germany & 83124418 & 77 & 225 & 44576.917 \\
\hline Italy & 60627291 & 70 & 207 & 70432.141 \\
\hline Switzerland & 8525611 & 74 & 204 & 81198.962 \\
\hline Andorra & 77006 & 88 & 183 & 179667.379 \\
\hline Denmark & 5752126 & 88 & 136 & 50743.387 \\
\hline Czech Republic & 10665677 & 74 & 136 & 155658.773 \\
\hline Poland & 37921592 & 60 & 122 & 76088.436 \\
\hline Portugal & 10256193 & 65 & 112 & 85856.051 \\
\hline Slovakia & 5453014 & 54 & 111 & 71720.074 \\
\hline Albania & 2882740 & 60 & 107 & 46046.633 \\
\hline Austria & 8891388 & 66 & 106 & 72206.875 \\
\hline France & 64990511 & 80 & 105 & 86325.089 \\
\hline Hungary & 9707499 & 71 & 105 & 83645.21 \\
\hline Turkey & 82340088 & 75 & 105 & 64196.94 \\
\hline Slovenia & 2077837 & 55 & 104 & 123742.383 \\
\hline Moldova & 4051944 & 43 & 99 & 63613.375 \\
\hline Spain & 46692858 & 80 & 99 & 81117.733 \\
\hline Serbia & 8802754 & 56 & 91 & 105279.579 \\
\hline Romania & 19506114 & 54 & 89 & 56174.491 \\
\hline North Macedonia & 2082957 & 58 & 83 & 74722.806 \\
\hline Greece & 10522246 & 79 & 80 & 40416.745 \\
\hline Bosnia and Herzegovina & 3323925 & 48 & 75 & 62481.731 \\
\hline Croatia & 4156405 & 57 & 75 & 87610.845 \\
\hline Ireland & 4818690 & 63 & 74 & 55002.07 \\
\hline Ukraine & 44246156 & 69 & 73 & 52556.15 \\
\hline Bulgaria & 7051608 & 75 & 63 & 60682.066 \\
\hline Belarus & 9452617 & 78 & 46 & 44001.045 \\
\hline Montenegro & 627809 & 67 & 44 & 159544.758 \\
\hline Lithuania & 2801264 & 68 & 42 & 102372.965 \\
\hline Latvia & 1928459 & 68 & 29 & 72759.97 \\
\hline Estonia & 1322920 & 69 & 27 & 98740.406 \\
\hline Sweden & 9971638 & 87 & 23 & 107819.278 \\
\hline Norway & 5337962 & 82 & 17 & 24116.983 \\
\hline Finland & 5522576 & 85 & 16 & 17176.113 \\
\hline Iceland & 336713 & 94 & 3 & 19208.791 \\
\hline
\end{tabular}

Table 2. Demographic characteristics and the accumulated number of laboratoryconfirmed COVID-19 cases in European countries as of June 28, 2021 
medRxiv preprint doi: https://doi.org/10.1101/2021.07.04.21259980; this version posted July 6,2021 . The copyright holder for this preprint (which was not certified by peer review) is the author/funder, who has granted medRxiv a license to display the preprint in perpetuity. All rights reserved. No reuse allowed without permission.

\section{Results}

The CC values (per 100 persons, blue "crosses") versus the volume of population, its density and the urbanization level are shown in Figs. 1-6. We have used datasets from Tables 1 and 2 . The best fitting lines (black) were calculated by the least squares method [25]. The linear regression was used to calculate the regression coefficient $r$ and the coefficients $a$ and $b$ of corresponding straight lines, [25]:

$$
C C=a+b x
$$

where $x$ is the volume of population $N_{\text {pop }}$ (Figs. 1 and 2), its density per square km (Figs. 3 and 4), and the urbanization level $\mathrm{N}_{\text {urb }} / N_{\text {pop }}$ (Figs. 5 and 6).

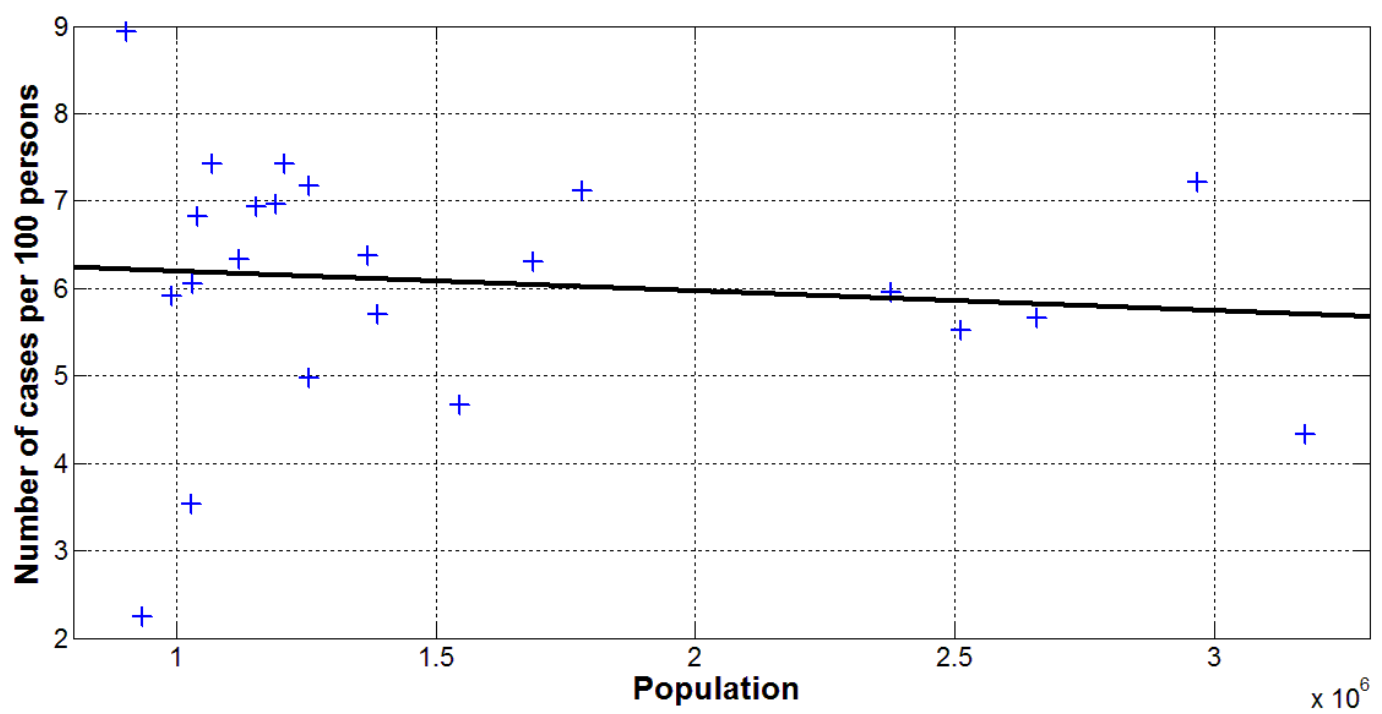

Fig.1. COVID-19 cases per 100 persons versus volume of population registered in the regions of Ukraine as of June 27, 2021

Blue "crosses" show the accumulated number of laboratory-confirmed cases per 100 persons (Table 1). The best fitting line (3) is shown in black.

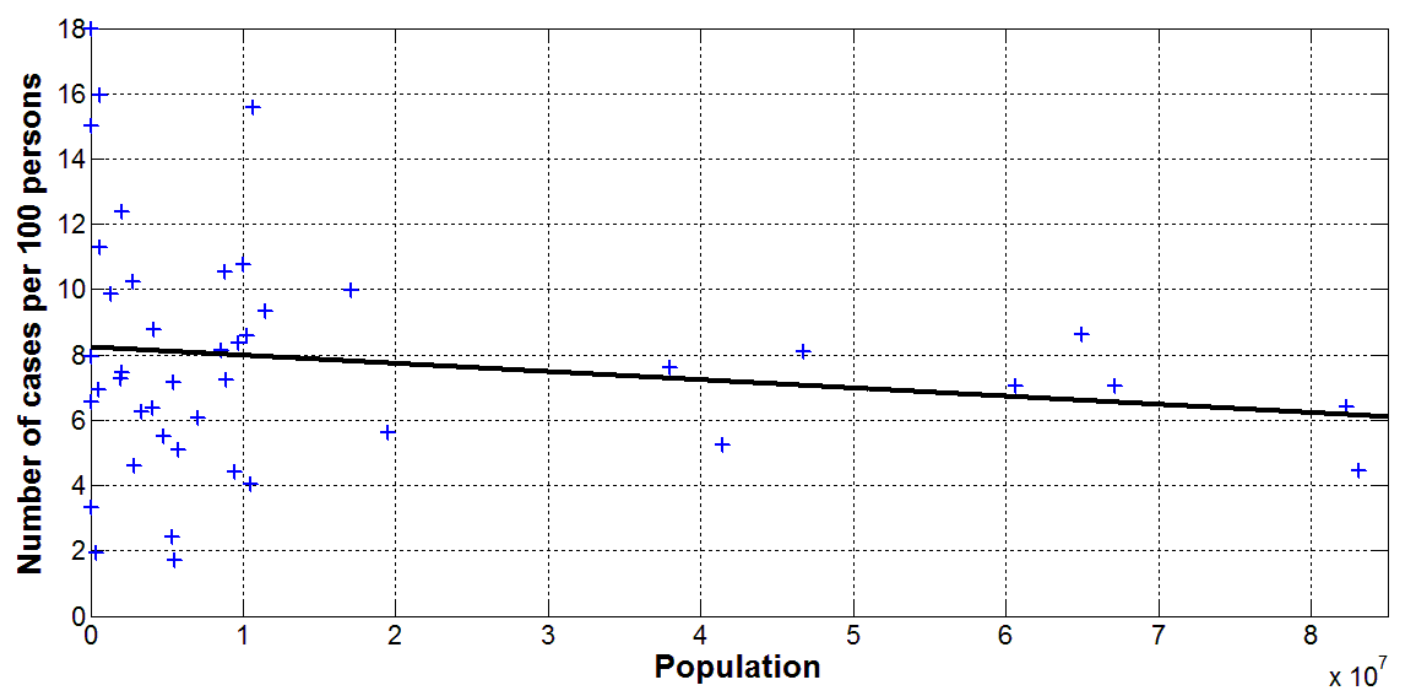

Fig.2. COVID-19 cases per 100 persons versus volume of population registered in the European countries as of June 28, 2021

Blue "crosses" show the accumulated number of laboratory-confirmed cases per 100 persons (Table 2). The best fitting line (3) is shown in black. 
medRxiv preprint doi: https://doi.org/10.1101/2021.07.04.21259980; this version posted July 6,2021 . The copyright holder for this preprint (which was not certified by peer review) is the author/funder, who has granted medRxiv a license to display the preprint in perpetuity. All rights reserved. No reuse allowed without permission.

Figs. 1 and 2 illustrate that there is no visible correlation between $\mathrm{CC}$ values and the volume of population both in the case of Ukrainian regions and European countries. We can see only slight decreasing of CC values with increasing of $N_{\text {pop }}$. The same tendency was revealed in [19] for the $\bar{V}_{\infty}$ (see eq. (1)). Corresponding values of $r, a, b$ and the number $n$ of regions or countries taken for calculations are shown in Table 3.

\begin{tabular}{|l|l|l|l|l|l|l|}
\hline $\begin{array}{l}\text { Number } \\
\text { of figure }\end{array}$ & $n$ & $\begin{array}{c}\text { Correlation } \\
\text { coefficient } \\
r\end{array}$ & $\begin{array}{c}\text { Optimal values } \\
\text { of parameters } \\
a\end{array}$ \\
in (3) & $\begin{array}{l}\text { Optimal values } \\
\text { of parameters } \\
b\end{array}$ & $\begin{array}{l}\text { Exitical } \\
\text { in (3) } \\
\text { value of } \\
\text { visher of the } \\
\text { Fisher function } \\
\begin{array}{l}\text { E, eq. } \\
m=2\end{array}\end{array}$ & $\begin{array}{l}\text { Function } \\
F_{c}(1, n-2) \\
\text { for the } \\
\text { confidence } \\
\text { level 0.1, } \\
{[26]}\end{array}$ \\
\hline 1 & 23 & -0.1082 & 6.4203 & $-2.2551 \mathrm{e}-007$ & 0.2486 & 2.96 \\
\hline 2 & 44 & -0.1607 & 8.2330 & $-2.5094 \mathrm{e}-008$ & 1.1132 & 2.84 \\
\hline 3 & 23 & 0.1792 & 5.9935 & $3.5699 \mathrm{e}-004$ & 0.6967 & 2.96 \\
\hline 4 & 44 & -0.0953 & 8.0331 & $-7.7955 \mathrm{e}-004$ & 0.3848 & 2.84 \\
\hline 5 & 23 & -0.1024 & 6.6956 & -1.0123 & 0.2224 & 2.96 \\
\hline 6 & 44 & -0.0019 & 7.8739 & -0.0394 & $1.5088 \mathrm{e}-004$ & 2.84 \\
\hline
\end{tabular}

Table 3. Optimal values of parameters in eq. (3), correlation coefficients and the results of Fisher test applications.

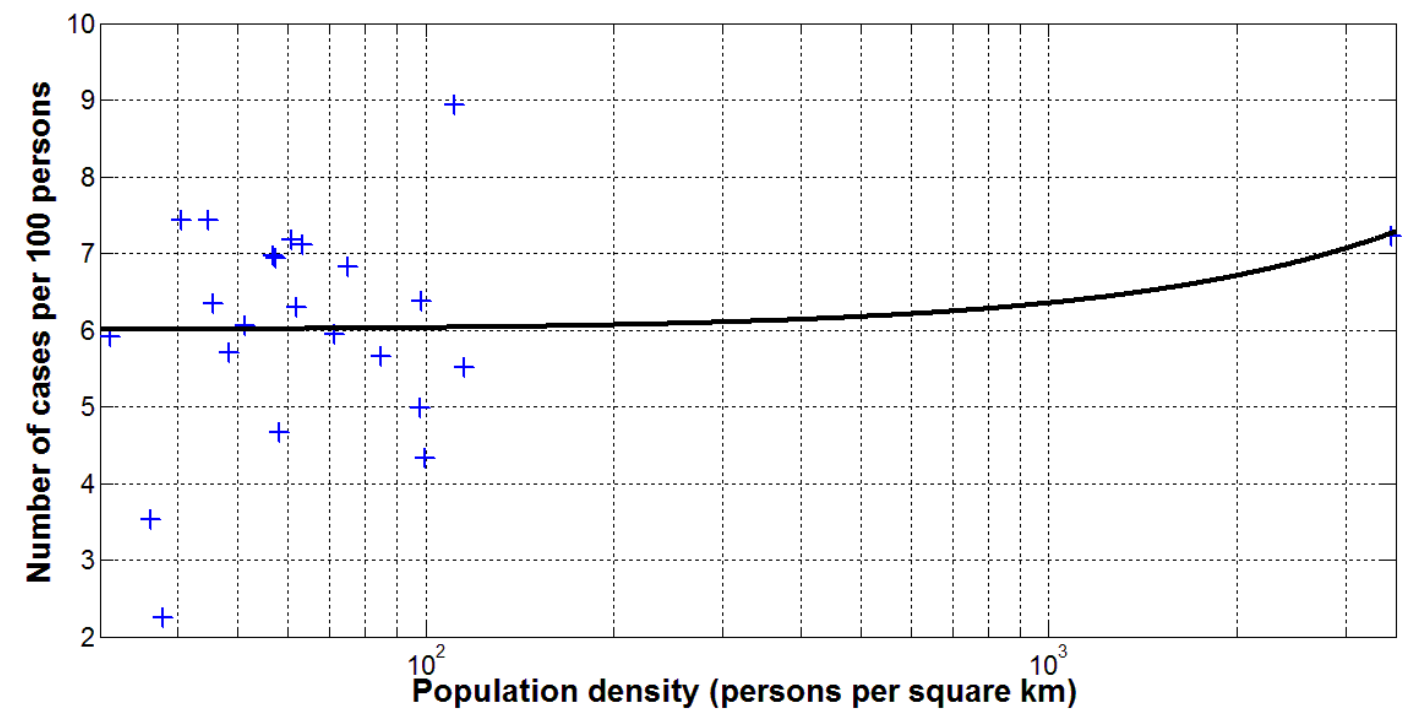

Fig. 3. COVID-19 cases per 100 persons versus density of population (per square km) registered in the regions of Ukraine as of June 27, 2021

Blue "crosses" show the accumulated number of laboratory-confirmed cases per 100 persons (Table 1). The best fitting line (3) is shown in black. 
medRxiv preprint doi: https://doi.org/10.1101/2021.07.04.21259980; this version posted July 6,2021 . The copyright holder for this preprint (which was not certified by peer review) is the author/funder, who has granted medRxiv a license to display the preprint in perpetuity.

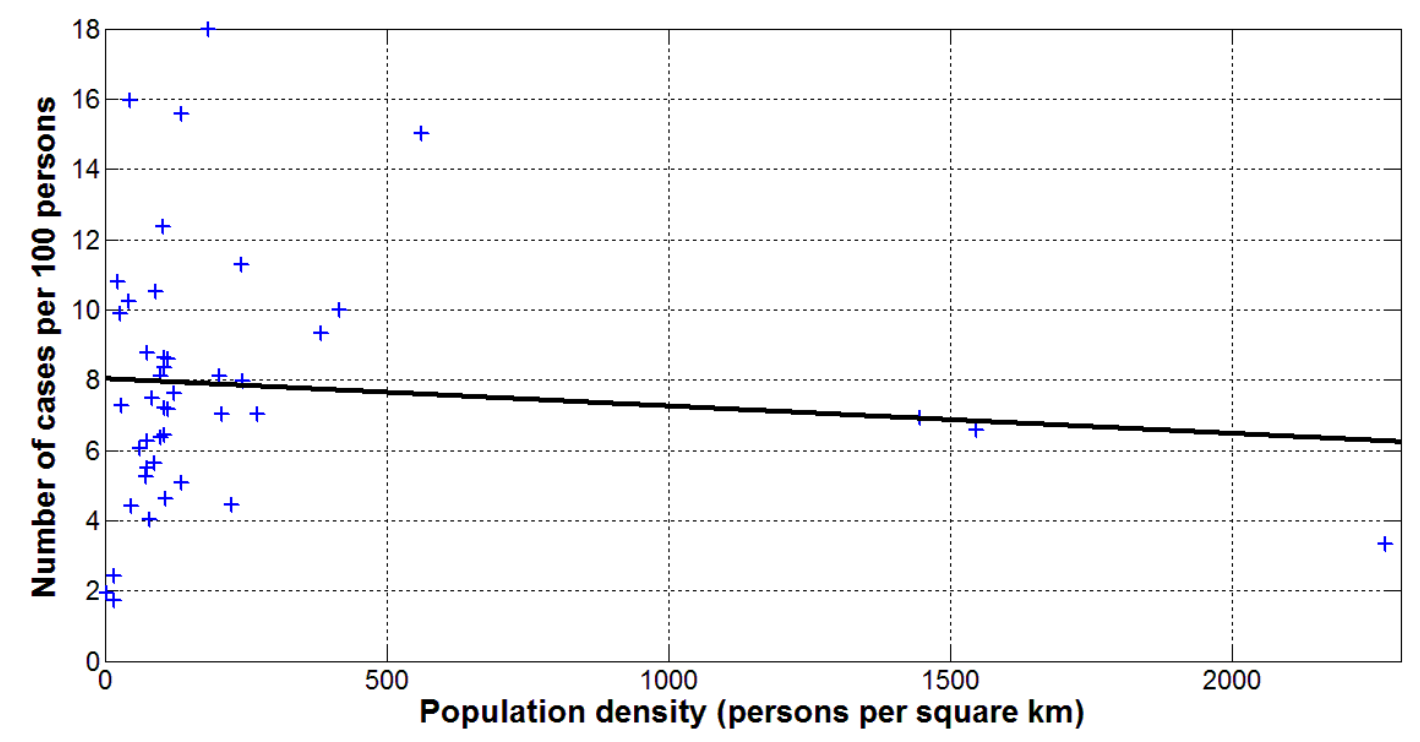

Fig. 4. COVID-19 cases per 100 persons versus density of population (per square km) registered in the European countries as of June 28, 2021

Blue "crosses" show the accumulated number of laboratory-confirmed cases per 100 persons (Table 2). The best fitting line (3) is shown in black.

Figs. 3-6 and Table 3 illustrate that $\mathrm{CC}$ values do not correlate with the density of population and the urbanization level both in the case of Ukrainian regions and European countries. In Fig. 3 we can see only slight increasing of CC values with increasing of the density of population in Ukrainian regions. Opposite trend is visible in Fig. 4 for European countries. The corresponding values of the correlation coefficient and parameter $b$ have opposite signs. In Figs. 5 and 6 we can see a slight decreasing of CC values with increasing the level of urbanization $N_{u b r} / N_{p o p}$.

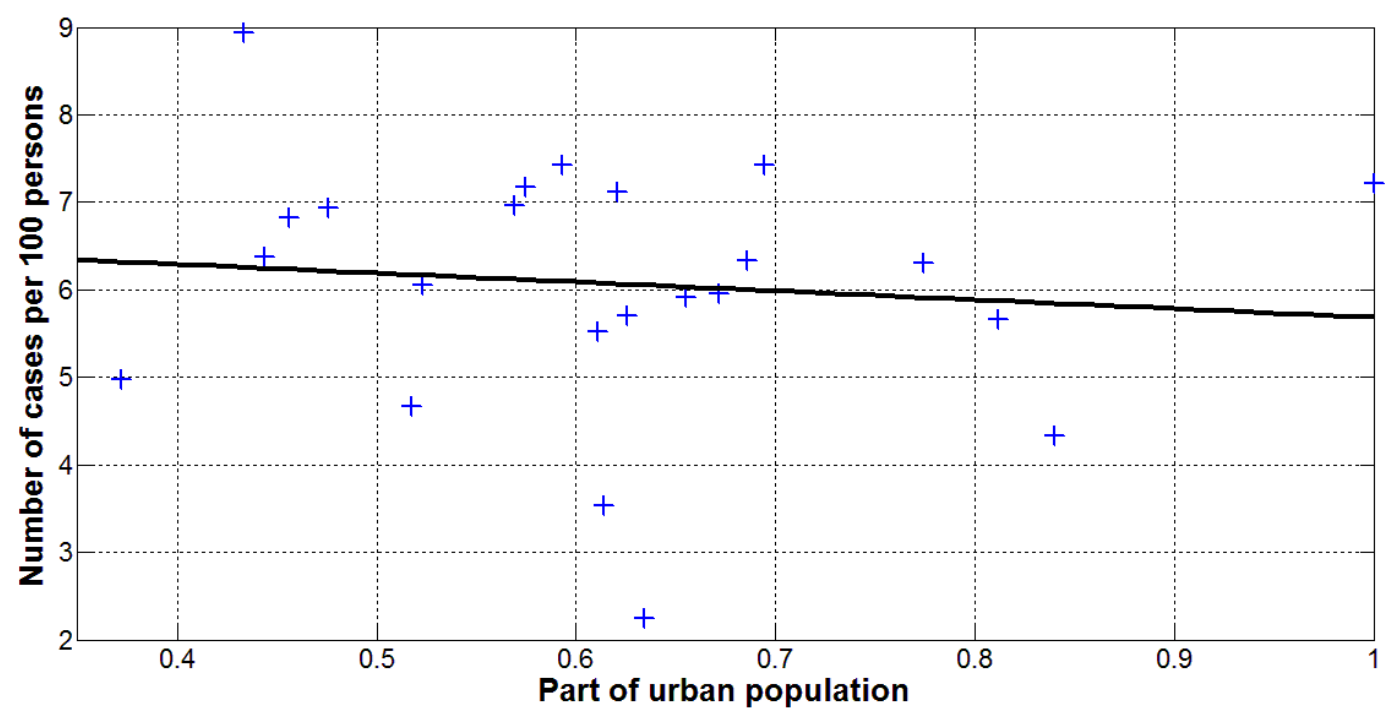

Fig. 5. COVID-19 cases per 100 persons versus part of the urban population $N_{u b r} / N_{p o p}$ registered in the regions of Ukraine as of June 27, 2021

Blue "crosses" show the accumulated number of laboratory-confirmed cases per 100 persons (Table 1). The best fitting line (3) is shown in black. 


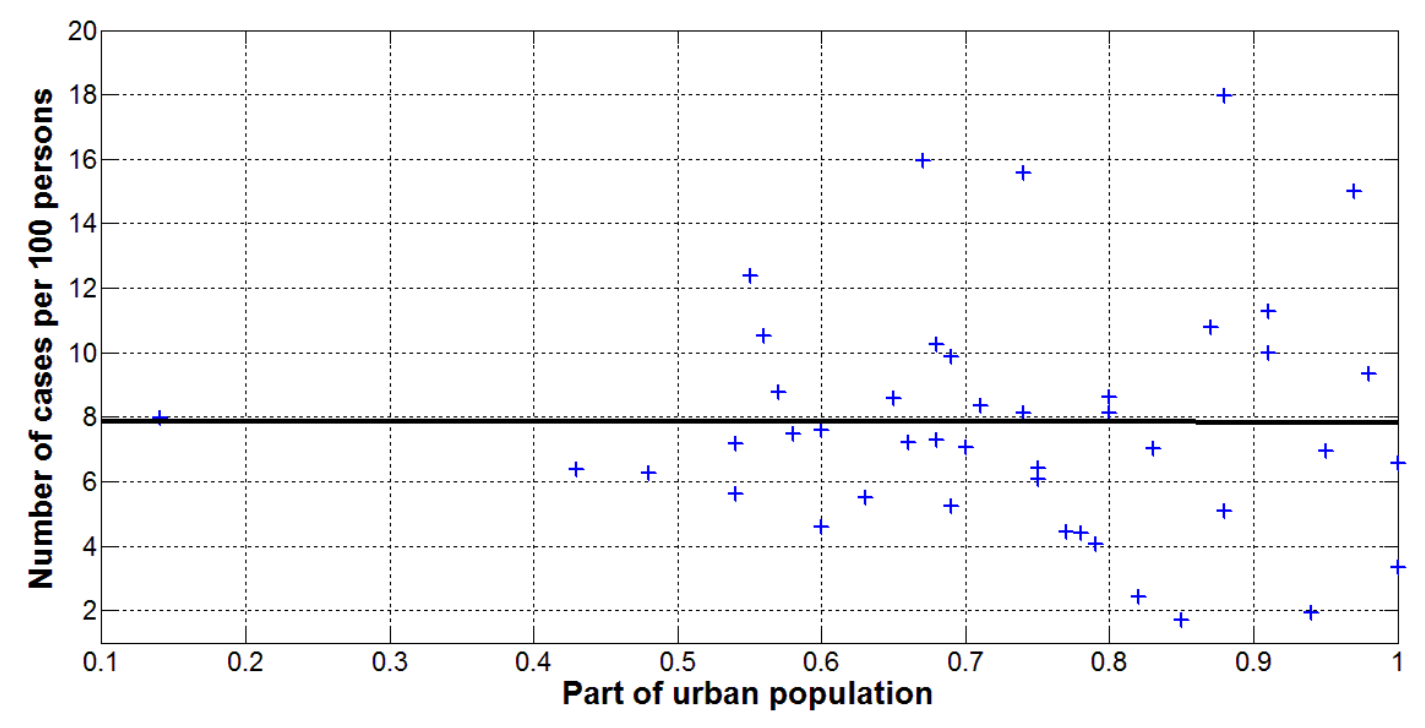

Fig. 6. COVID-19 cases per 100 persons versus part of the urban population $N_{u b r} / N_{p o p}$ population registered in the European countries as of June 28, 2021

Blue "crosses" show the accumulated number of laboratory-confirmed cases per 100 persons (Table 2). The best fitting line (3) is shown in black.

\section{Discussion}

We can use also the F-test for the null hypothesis that says that the proposed linear relationship (3) fits the data sets. The experimental values of the Fisher function can be calculated with the use of the formula:

$$
F=\frac{r^{2}(n-m)}{\left(1-r^{2}\right)(m-1)}
$$

where $m=2$ is the number of parameters in the regression equation, [25]. The corresponding experimental values $F$ are shown in Table 3. They have to be compared with the critical values $F_{C}\left(k_{1}, k_{2}\right)$ of the Fisher function at a desired significance or confidence level $\left(k_{1}=m-1, k_{2}=n-m\right.$, see, e.g., [26]). Comparisons of the values in the last two columns of Table 3 show that the critical values are much higher than the experimental $F$ values. It means that the data sets presented in Tables 1 and 2 do not support the linear relationship (3).

We have checked also the non-linear dependences:

$$
C C=\delta x^{\eta}
$$


medRxiv preprint doi: https://doi.org/10.1101/2021.07.04.21259980; this version posted July 6, 2021. The copyright holder for this preprint (which was not certified by peer review) is the author/funder, who has granted medRxiv a license to display the preprint in perpetuity. All rights reserved. No reuse allowed without permission.

instead of (3) as it was done in $[19,27,28]$. Similar to the case of linear dependence (3), the calculations showed that corresponding values $|r|<<1$ and $F_{C}\left(k_{1}, k_{2}\right)>F$. It means that hypothesis (5) was not also supported by the datasets presented in Tables 1 and 2.

Very different $\mathrm{CC}$ values registered in the regions of Ukraine and European countries could be a result of different coronavirus strains, quarantine measures, testing, tracing and isolating patients. One more reason may be the large number of unregistered cases observed in many countries [29-33]. Estimates for Ukraine and Qatar made in [29, 33] showed that the real number of cases is about 4-5 times higher than registered and reflected in the official statistics. Similar estimates can be made for the regions of Ukraine and other European countries.

If we apply the visibility coefficients $\beta_{10}=3.7$ and $\beta_{3}=5.308$ calculated for the Ukraine and Qatar (see [29,33]) and take accumulated numbers of laboratory-confirmed cases, the CC values could be estimated as $20 \%$ in Ukraine and $42 \%$ in Qatar (as of the end of June 2021). Such a high percentage of people who catch the coronavirus infection can significantly affect the evaluation of the vaccination efficiency. Probably this is why we do not yet see the effect of vaccination on the pandemic dynamics in Qatar, [34].

The highest $\mathrm{CC}$ values registered in Europe are close to ones in other regions, e.g., Seychelles-15.8\%, Bahrain-15.6\%. The lowest CC values in Europe is much higher than in Vanuatu, Micronesia, Tanzania (around 0.001\%), and China (0.006\%). Very small CC values in the WHO Western Pacific region (e.g. Vietnam - 0.017\%; Laos - 0.029\%; South Korea, Cambodia $-0.3 \%$; and $0.63 \%$ for Japan) need special investigations, but let us express some hypotheses.

First of all the COVID-19 pandemic probably started in this region in August 2019, [18]. It means that first cases were not identified and registered during at least 4 months. Probably these first cases were not very severe and the symptoms were not so pronounced. Presumably mutations of the coronavirus made it more pathogenic and sick people became more noticeable in December 2019. But previous cases were not taken into account in the statistics. Recent DNA investigations of East Asia population reported the presence of coronavirus around 20,000 years ago [35]. Probably, the population of this region had a collective immunity to pathogens similar to Covid-19 before the pandemic. 
medRxiv preprint doi: https://doi.org/10.1101/2021.07.04.21259980; this version posted July 6,2021 . The copyright holder for this preprint (which was not certified by peer review) is the author/funder, who has granted medRxiv a license to display the preprint in perpetuity.

All rights reserved. No reuse allowed without permission.

\section{References}

1. World Health Organization. "Coronavirus disease (COVID-2019) situation reports". https://www.who.int/emergencies/diseases/novel-coronavirus-2019/situation-reports/. Retrieved Oct. 3, 2020.

2. COVID-19 Data Repository by the Center for Systems Science and Engineering (CSSE) at Johns Hopkins University (JHU). https://github.com/owid/covid-19-data/tree/master/public/data

3. Byass, P. Eco-epidemiological assessment of the COVID-19 epidemic in China, January-Februry 2020. medRxiv 2020, doi:10.1101/2020.03.29.20046565.

4. Dehning J. et al. Inferring COVID-19 spreading rates and potential change points for case number forecasts. Preprint, ArXiv:2004.01105(2020).

5. Distante, C.; Gadelha Pereira, I.; Garcia Goncalves, L.M.; Piscitelli, P.; Miani, A. Forecasting Covid-19 Outbreak Progression in Italian Regions: A model based on neural network training from Chinese data. medRxiv 2020.

6. Hamzah, F.; Binti, A.; Lau, C.; Nazri, H.; Ligot, D.V.; Lee, G.; Tan, C.L. CoronaTracker: Worldwide COVID-19 Outbreak Data Analysis and Prediction. Bull. World Health Organ. 2020, 1, 32.

7. Fanelli, D.; Piazza, F. Analysis and forecast of COVID-19 spreading in China, Italy and France. Chaos Solitons Fractals 2020, 134, 109761.

8. Webb, G.F.; Magal, P.; Liu, Z.; Seydi, O. A model to predict COVID-19 epidemics with applications to South Korea, Italy, and Spain. medRxiv 2020.

9. Distante, C.; Piscitelli, P.; Miani, A. Covid-19 Outbreak Progression in Italian Regions: Approaching the Peak by the End of March in Northern Italy and First Week of April in Southern Italy. Int. J. Environ. Res. Public Health 2020, 17, 3025.

10. KY Ng, MM Gui. COVID-19: Development of a robust mathematical model and simulation package with consideration for ageing population and time delay for control action and resusceptibility. Physica D: Nonlinear Phenomena.Volume 411, October 2020, 132599

https://doi.org/10.1016/j.physd.2020.132599

11. Diego Carvalho, Rafael Barbastefano, Dayse Pastore, Maria Clara Lippi.

A novel predictive mathematical model for COVID-19 pandemic with quarantine, contagion dynamics, and environmentally mediated transmission. medRxiv 2020.07.27.20163063;

doi: https://doi.org/10.1101/2020.07.27.20163063

12. Piotr T. Chruściel, Sebastian J. Szybka. Universal properties of the dynamics of the Covid-19 pandemics. medRxiv 2020.08.24.20181214;

doi: https://doi.org/10.1101/2020.08.24.20181214

13. Gyan Bhanot, Charles DeLisi. Analysis of Covid-19 Data for Eight European Countries and the United Kingdom Using a Simplified SIR Model.

medRxiv 2020.05.26.20114058;

doi: https://doi.org/10.1101/2020.05.26.20114058

14. Lia Humphrey et al. TESTING, TRACING AND SOCIAL DISTANCING: ASSESSING OPTIONS FOR THE CONTROL OF COVID 19 . medRxiv 2020.04.23.20077503;

doi: https://doi.org/10.1101/2020.04.23.20077503

15. Md. Haider Ali Biswas, M. S. Khatun, A. K. Paul, M. R. Khatun, M. A. Islam, S. A. Samad, U. Ghosh. Modeling the Effective Control Strategy for Transmission Dynamics of Global Pandemic COVID19. medRxiv 2020.04.22.20076158; doi: https://doi.org/10.1101/2020.04.22.20076158

16. Elinor Aviv-Sharon, Asaph Aharoni. Forecasting COVID-19 pandemic Severity in Asia. medRxiv. doi: https://doi.org/10.1101/2020.05.15.20102640

17. Ashok Krishnamurthy. Spatiotemporal Transmission Dynamics of COVID-19 in Spain. Conference: Advancing knowledge about spatial modeling, infectious diseases, environment and health (June 8-12, 2020). 
medRxiv preprint doi: https://doi.org/10.1101/2021.07.04.21259980; this version posted July 6,2021 . The copyright holder for this preprint (which was not certified by peer review) is the author/funder, who has granted medRxiv a license to display the preprint in perpetuity. All rights reserved. No reuse allowed without permission.

https://www.researchgate.net/publication/342247591_Spatiotemporal_Transmission_Dynamics_of_COVI D-19_in_Spain

18. Nesteruk I. COVID19 pandemic dynamics. Springer Nature, 2021, https://link.springer.com/book/10.1007/978-981-33-6416-5

19. Nesteruk I. Comparison of the First Waves of the COVID-19 Pandemic in Different Countries and Regions. In book: COVID19 pandemic dynamics. Springer Nature, 2021, https://link.springer.com/chapter/10.1007/978-981-33-6416-5 7

20. https://index.minfin.com.ua/reference/coronavirus/ukraine/

21.

https://uk.wikipedia.org/wiki/\%D0\%A1\%D0\%BF\%D0\%B8\%D1\%81\%D0\%BE\%D0\%BA_\%D0\%BE\%D 0\%B1\%D0\%BB\%D0\%B0\%D1\%81\%D1\%82\%D0\%B5\%D0\%B9 \%D0\%A3\%D0\%BA\% $\% 1 \% 80 \% \mathrm{D} 0 \%$ B0\%D1\%97\%D0\%BD\%D0\%B8 \%D0\%B7\%D0\%B0 \%D1\%87\%D0\%B8\%D1\%81\%D0\%B5\%D0\%BB $\% \mathrm{D} 1 \% 8 \mathrm{C} \% \mathrm{D} 0 \% \mathrm{BD} \% \mathrm{D} 1 \% 96 \% \mathrm{D} 1 \% 81 \% \mathrm{D} 1 \% 82 \% \mathrm{D} 1 \% 8 \mathrm{E}+\% \mathrm{D} 0 \% \mathrm{BD} \% \mathrm{D} 0 \% \mathrm{~B} 0 \% \mathrm{D} 1 \% 81 \% \mathrm{D} 0 \% \mathrm{~B} 5 \% \mathrm{D}$ $0 \% \mathrm{BB} \% \mathrm{D} 0 \% \mathrm{~B} 5 \% \mathrm{D} 0 \% \mathrm{BD} \% \mathrm{D} 0 \% \mathrm{BD} \% \mathrm{D} 1 \% 8 \mathrm{~F}$

\section{2. https://en.wikipedia.org/wiki/List_of_European_countries_by_population}

23. https://en.wikipedia.org/wiki/European_countries_by_percentage_of_urban_population

24. https://www.indexmundi.com/map/?v=21000\&r=eu\&l=en

25. Draper NR, Smith H. Applied regression analysis. 3rd ed. John Wiley; 1998.

26. https://onlinepubs.trb.org/onlinepubs/nchrp/cd-22/manual/v2appendixc.pdf

27. Gazzola M., Argentina M. \& L. Mahadevan. Scaling macroscopic aquatic locomotion. Nature Physics volume 10, pages 758-761 (2014).

28. I. Nesteruk, "Maximal speed of underwater locomotion", Innov Biosyst Bioeng, 2019, vol. 3, no. 3, pp. 152-167. Doi: https://doi.org/10.20535/ibb.2019.3.3.177976

29. Nesteruk I. Visible and real sizes of new COVID-19 pandemic waves in Ukraine Innov Biosyst Bioeng, 2021, vol. 5, no. 2, pp. 85-96. DOI: 10.20535/ibb.2021.5.2.230487 http://ibb.kpi.ua/article/view/230487

30. https://podillyanews.com/2020/12/17/u-shkolah-hmelnytskogo-provely-eksperyment-z-testuvannyamna-covid-19/

31. https://edition.cnn.com/2020/11/02/europe/slovakia-mass-coronavirus-test-intl/index.html

32. https://www.voanews.com/covid-19-pandemic/slovakias-second-round-coronavirus-tests-draws-largecrowds

33. Nesteruk I. Impact of vaccination and undetected cases on the COVID-19 pandemic dynamics in Qatar in 2021. [Preprint] MedRxiv, June 2021. DOI: $\underline{10.1101 / 2021.05 .27 .21257929}$ https://medrxiv.org/cgi/content/short/2021.05.27.21257929v1

34. Nesteruk I.The real COVID-19 pandemic dynamics in Qatar in 2021: SIR simulations, predictions and verifications. [Preprint] Research Gate, June 2021. DOI: 10.13140/RG.2.2.32904.55044

35. https://www.nytimes.com/2021/06/24/science/ancient-coronavirus-epidemic.html 